\title{
SEASONAL VARIATION IN SOURCES OF DISSOLVED ORGANIC CARBON IN A LACUSTRINE ENVIRONMENT REVEALED BY PAIRED ISOTOPIC MEASUREMENTS $\left(\Delta^{14} \mathrm{C}\right.$ AND $\left.\delta^{13} \mathrm{C}\right)$
}

\author{
Fumiko Nara ${ }^{1,2} \cdot$ Akio Imai $^{1} \bullet$ Minoru Yoneda ${ }^{1,3} \cdot$ Kazuo Matsushige $^{1} \bullet$ Kazuhiro Komatsu $^{1} \bullet$ \\ Takashi Nagai $^{4} \cdot$ Yasuyuki Shibata $^{1} \cdot$ Takahiro Watanabe $^{5}$
}

\begin{abstract}
To investigate the sources and cycling of dissolved organic carbon (DOC) in a lacustrine environment, isotopic measurements of ${ }^{14} \mathrm{C}$ and ${ }^{13} \mathrm{C}$ in DOC were carried out for Lake Kasumigaura-which is famous as a very eutrophic and shallow (mean depth $4.0 \mathrm{~m}$ ) lake in central Japan-and its tributary rivers. Lake and river samples were collected in the spring and autumn (May and September) of 2003. The $\Delta^{14} \mathrm{C}$ measurements of DOC were performed using the accelerator mass spectrometer at the National Institute for Environmental Studies (NIES-TERRA), Japan. In September, the ${ }^{14} \mathrm{C}$ values of DOC were light (around $-200 \%$ ) and did not differ significantly between lake and river water samples, indicating that DOC in Lake Kasumigaura and its tributary rivers yields older ${ }^{14} \mathrm{C}$ ages than the age expected from the lake-water residence time (average 200 days). This result suggests that terrestrial sources are important contributors to DOC in Lake Kasumigaura. Nevertheless, $\delta^{13} \mathrm{C}$ values indicated that during spring, DOC in the lake is mainly autochthonous. Thus, sources and cycling of DOC in Lake Kasumigaura may vary seasonally.
\end{abstract}

\section{INTRODUCTION}

Dissolved organic carbon (DOC) is defined as organic carbon in water that has been passed through a membrane filter with a pore size of $\sim 0.7 \mu \mathrm{m}$ or a glass fiber filter. In seawater, the reservoir of DOC is estimated to be $0.6 \times 10^{18} \mathrm{~g}$ carbon (Hedges 1992). Thus, DOC may play an important role in the global carbon cycle on Earth. To understand the sources and sinks of DOC in aquatic environments such as estuaries, continental margins, and lakes, numerous studies have been carried out (Doval et al. 1999; Hopkinson et al. 2002; Repeta et al. 2002; Brown et al. 2004; Simjouw et al. 2005). Nevertheless, DOC sources are still poorly understood because DOC is a heterogeneous mixture of organic compounds and its physicochemical characteristics are very difficult to elucidate. New analytical approaches in characterizing DOC are definitely needed.

Paired carbon isotopic measurements $\left(\Delta^{14} \mathrm{C}\right.$ and $\left.\delta^{13} \mathrm{C}\right)$ of DOC $\left(\Delta^{14} \mathrm{C}_{\mathrm{DOC}}\right.$ and $\left.\delta^{13} \mathrm{C}_{\mathrm{DOC}}\right)$ can be used as an effective tool for investigating DOC sources in aquatic environments. Generally, the $\delta^{13} \mathrm{C}$ of organic matter is used to estimate relative amounts of organic matter of either autochthonous or allochthonous origin in the paleoenvironment (Meyers and Ishiwatari 1993). Since the use of isotope mass spectrometers became more routine, studies measuring DOC $\delta^{13} \mathrm{C}$ in marine and coastal water samples have become more common (Cifuentes and Eldridge 1998; Kelly et al. 1998). However, there are few studies of $\delta^{13} \mathrm{C}$ of lake DOC. Furthermore, because $\delta^{13} \mathrm{C}$ values vary within a narrow range (about $-30 \%$ o to $-15 \%$; Kelly et al. 1998), considerable overlap exists in $\delta^{13} \mathrm{C}$ values of organic matter in lacustrine environments (Yamada et al. 1996). On the other hand, $\Delta^{14} \mathrm{C}$ values of natural samples have a greater dynamic range (about $-1000 \%$ to $250 \%$ ). Therefore, $\Delta^{14} \mathrm{C}$ measurements of DOC can provide additional and unique information, particularly regarding DOC

\footnotetext{
'National Institute for Environmental Studies, 16-2 Onogawa, Tsukuba, Ibaraki 305-8506, Japan.

${ }^{2}$ Corresponding author. Email: nara.fumiko@nies.go.jp.

${ }^{3}$ Present address: Graduate School of Frontier Sciences, University of Tokyo, Bioscience Bldg 502, Kashiwanoha 5-1-5, Kashiwa, Chiba 277-8562, Japan.

${ }^{4}$ Graduate School of Life and Environmental Sciences, University of Tsukuba, 1-1-1 Tennoudai, Tsukuba, Ibaraki 305-8572, Japan.

${ }^{5}$ Center for Chronological Research, Nagoya University, Furo-cho, Chikusa, Nagoya 464-8602, Japan.
} 
age and residence time. Paired isotopic measurements of $\Delta^{14} \mathrm{C}$ and $\delta^{13} \mathrm{C}$ may thus allow a greater degree of differentiation of DOC sources than measurements of either $\Delta^{14} \mathrm{C}$ or $\delta^{13} \mathrm{C}$ alone.

In this study, to evaluate potential sources of DOC in a lacustrine environment (Lake Kasumigaura, Japan) from paired isotopic $\left(\Delta^{14} \mathrm{C}\right.$ and $\left.\delta^{13} \mathrm{C}\right)$ measurements, we carried out a seasonal analysis of $\Delta^{14} \mathrm{C}$ and $\delta^{13} \mathrm{C}$ in lake and river DOC samples.

\section{STUDY AREA AND SAMPLE COLLECTION}

Lake Kasumigaura in central Japan $\left(36^{\circ} \mathrm{N}, 140^{\circ} \mathrm{E}\right)$ is Japan's second largest lake (Figure 1). Because the lake basin is smooth and shallow (mean depth $4.0 \mathrm{~m}$, maximum depth $7.3 \mathrm{~m}$ ), vertical stratification of the lake waters is easily destroyed by strong winds. Lake Kasumigaura has 4 large tributary rivers, the Koise, Sakura, Hanamuro, and Ono rivers, and a single outlet river. The water residence time in Lake Kasumigaura has been estimated to be about 200 days (World Lake Database, http://www.ilec.or.jp/database/database.html). Lake Kasumigaura is known to be highly eutrophic due to the high input of organic matter and nutrients to the lake. In August 2002, the concentrations of chlorophyll- $a$, phosphorus, and nitrogen were 77,152 , and $0.83 \mu \mathrm{g} / \mathrm{L}$, respectively, at the center of the lake (Lake Kasumigaura database, http://www-cger2.nies.go.jp/ gems/database/kasumi/top.html).

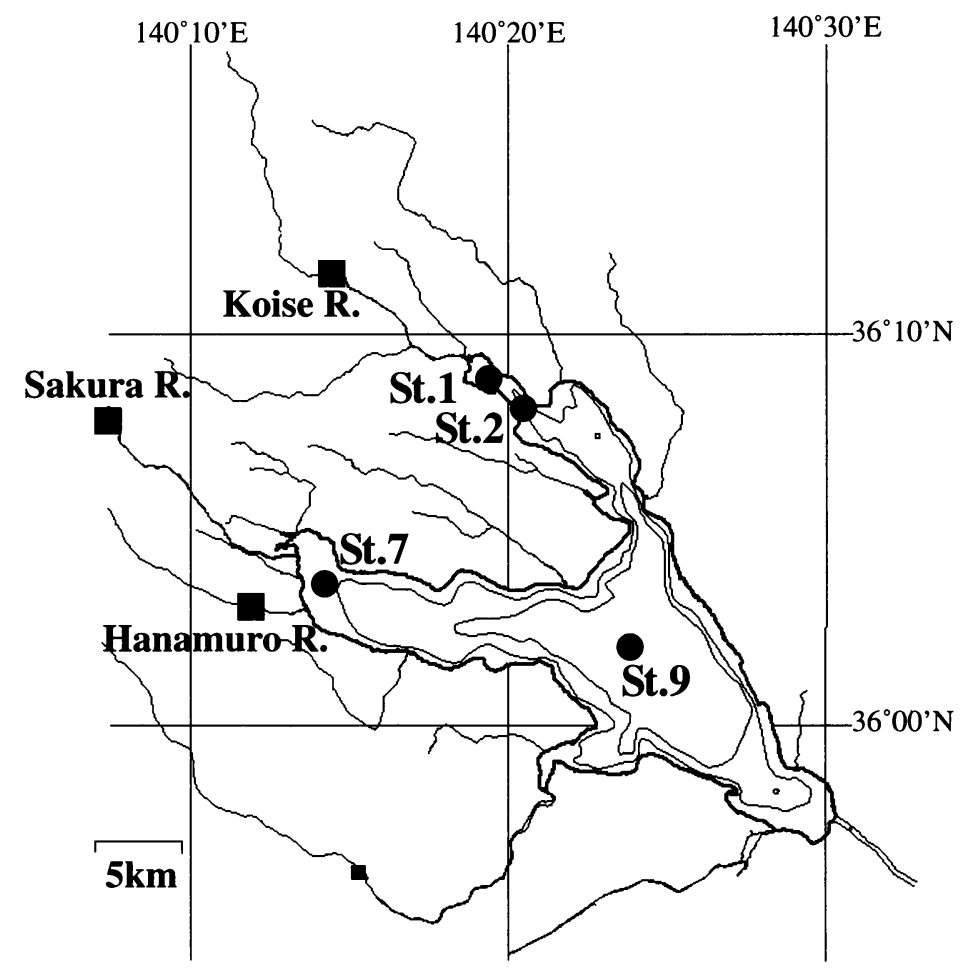

Figure 1 Map of Lake Kasumigaura showing sampling sites: surface sediment samples were collected at Station 9.

Surface water samples were collected in May and September 2003 at 7 sampling sites (Figure 1). The samples were immediately cooled by putting them in a cooler on ice and brought back to our laboratory. The water samples were filtered through a precombusted $\left(450{ }^{\circ} \mathrm{C}\right.$ for $4 \mathrm{hr}$ ) Whatman 
$\mathrm{GF} / \mathrm{F}$ filter (nominal pore size $0.7 \mu \mathrm{m}$ ), and the filtrate was freeze-dried for isotopic measurements. Surface sediment samples were collected at Station 9 in January, May, September, and November 2003 just as for the water samples; the surface sediment samples were also freeze-dried for isotopic measurements.

\section{ANALYTICAL METHODS}

The DOC and sediment samples for carbon isotopic analysis were treated with $6 \mathrm{M} \mathrm{HCl}$ and $1.2 \mathrm{M}$ $\mathrm{HCl}$, respectively, to remove inorganic carbonate prior to the isotopic measurements. Before ${ }^{14} \mathrm{C}$ analysis by accelerator mass spectrometry (AMS), purified $\mathrm{CO}_{2}$ gases of DOC samples were prepared with a system comprising an elemental analyzer connected to cryogenic traps (EA-CT). The EA-CT system was described in detail in Yoneda et al. (2004). The purified $\mathrm{CO}_{2}$ was reduced to graphite with $\mathrm{H}_{2}$ over $\mathrm{Fe}$ at $650{ }^{\circ} \mathrm{C}$ over $8 \mathrm{hr} .{ }^{14} \mathrm{C}$ analysis of the graphite target was conducted at the AMS facility of the National Institute for Environmental Studies (NIES-TERRA). ${ }^{14} \mathrm{C}$ results are expressed as the per mil difference $\left(\Delta^{14} \mathrm{C}\right)$ relative to the international standard of oxalic acid. $\Delta^{14} \mathrm{C}$ values were corrected for fractionation using the $\delta^{13} \mathrm{C}$ values of the samples in accordance with the conventions of Stuiver and Polach (1977).

The $\delta^{13} \mathrm{C}$ values of DOC and sediment samples were measured using an elemental analyzer (Thermo Flash 112 series) interfaced to an isotopic ratio mass spectrometer (Thermo Delta X Advantage) via a Conflo III split interface. Carbon isotopic compositions were calibrated using a laboratory organic carbon standard (L-alanine; Shohko-tsusho, $\delta^{13} \mathrm{C}=-19.03 \%$ ) and expressed as per mil (\%o) relative to Vienna Pee Dee belemnite (VPDB). Standard deviations of the $\delta^{13} \mathrm{C}$ measurements for DOC and sediment samples in duplicate analyses were generally less than $0.1 \%$.

\section{RESULTS AND DISCUSSION}

\section{$\Delta{ }^{14} \mathrm{C}$ Values in Lake Kasumigaura and Its Tributary Rivers}

The $\Delta^{14} \mathrm{C}$ of DOC $\left(\Delta^{14} \mathrm{C}_{\mathrm{DOC}}\right)$ values of the lake and river samples were light, ranging from $-235 \%$ o to $-75 \%$ and from $-355 \%$ o from $-221 \%$, respectively (Table 1). Although data on $\Delta^{14} \mathrm{C}_{\mathrm{DOC}}$ in lacustrine environments are still limited, our $\Delta^{14} \mathrm{C}_{\mathrm{DOC}}$ results for Lake Kasumigaura and its tributary rivers are clearly light compared with other reported data (Table 2). For example, Raymond and Bauer (2001a) reported heavy $\Delta^{14} C_{\text {DOC }}$ values in the York River estuary, ranging from $42 \%$ o to $257 \%$, for DOC from terrestrial sources that was photosynthetically fixed at least $15-20 \mathrm{yr}$ ago. In our study, the significant depletion of the river $\Delta^{14} \mathrm{C}_{\mathrm{DOC}}$ values suggests that it is likely that the residence time of DOC in the watershed around Lake Kasumigaura is long, perhaps thousands of years. Because DOC can be effectively retained by soil, a long time may pass before DOC is exported from the watershed into the river system (Kaiser et al. 1996). Kaiser and Guggenberger (2000) also reported that recalcitrant DOC, such as lignin, has a strong tendency to adsorb to mineral surfaces. Furthermore, a certain fraction of DOC is considered biologically inert and undergoes recycling in the ocean (Williams and Druffel 1987). Therefore, the depleted $\Delta^{14} C_{D O C}$ values of the river samples suggest that the recalcitrant DOC fraction accounts for a large proportion of the river DOC.

The most highly ${ }^{14} \mathrm{C}$-enriched values, ranging from 0 to $10 \%$, were found in the lake surface sediment samples rather than in the lake and river DOC samples. Sedimentary organic matter is generally a mixture of autochthonous and allochthonous organic matter (Meyers 1997). Nevertheless, it seems the organic carbon in the lake surface sediments contributes relatively little to the DOC in the lake and river waters. This indicates that the residence times of DOC and 
Table $1 \Delta^{14} \mathrm{C}$ and $\delta^{13} \mathrm{C}$ values for DOC from Lake Kasumigaura and its tributary rivers, and for surface sediment ( $\mathrm{nd}=$ not determined).

\begin{tabular}{|c|c|c|c|c|}
\hline $\begin{array}{l}\text { Sampling } \\
\text { site }\end{array}$ & $\begin{array}{l}\text { Sampling } \\
\text { date }\end{array}$ & $\begin{array}{l}\delta^{13} \mathrm{C} \\
(\% o)\end{array}$ & $\begin{array}{l}\Delta^{14} \mathrm{C} \\
(\% o)\end{array}$ & $\begin{array}{l}{ }^{14} \mathrm{C} \text { age } \\
\text { (yr BP) }\end{array}$ \\
\hline \multicolumn{5}{|c|}{ Lake Kasumigaura } \\
\hline \multirow{2}{*}{ Station 1} & May 2003 & -24.2 & -75 & 625 \\
\hline & Sep 2003 & -25.9 & nd & nd \\
\hline \multirow[t]{2}{*}{ Station 2} & May 2003 & -24.2 & nd & nd \\
\hline & Sep 2003 & -25.6 & -164 & 1441 \\
\hline \multirow[t]{2}{*}{ Station 7} & May 2003 & -25.3 & -109 & 924 \\
\hline & Sep 2003 & -25.9 & -235 & 2147 \\
\hline \multirow[t]{2}{*}{ Station 9} & May 2003 & -25.1 & -114 & 976 \\
\hline & Sep 2003 & -25.9 & -211 & 1908 \\
\hline \multicolumn{5}{|l|}{ Rivers } \\
\hline \multirow[t]{2}{*}{ Koise } & May 2003 & -25.6 & nd & nd \\
\hline & Sep 2003 & -25.7 & -287 & 2718 \\
\hline \multirow[t]{2}{*}{ Sakura } & May 2003 & -25.8 & -243 & 2233 \\
\hline & Sep 2003 & -25.8 & -221 & 2010 \\
\hline \multirow[t]{2}{*}{ Hanamuro } & May 2003 & -25.9 & -352 & 3488 \\
\hline & Sep 2003 & -25.4 & -355 & 3525 \\
\hline \multicolumn{5}{|c|}{ Lake surface sediment } \\
\hline \multirow[t]{4}{*}{ Station 9} & Jan 03 & -25.4 & 10 & modern \\
\hline & May 03 & -26.0 & 10 & modern \\
\hline & Sep 03 & -25.5 & 10 & modern \\
\hline & Nov 03 & -25.4 & 0 & modern \\
\hline
\end{tabular}

Table $2 \Delta^{14} \mathrm{C}$ of DOC data in lake and rivers from published results.

\begin{tabular}{|c|c|c|c|}
\hline Source & $\begin{array}{l}\Delta^{14} \mathrm{C} \\
(\% o)\end{array}$ & $\begin{array}{l}{ }^{14} \mathrm{C} \text { age } \\
\text { (yr BP) }\end{array}$ & References \\
\hline Lake & & & \\
\hline $\begin{array}{l}\text { Harp Lake } \\
\text { Rivers }\end{array}$ & $116-158$ & Modern & Schiff et al. 1990 \\
\hline Amazon & 28 & Modern & Raymond and Bauer 2001b \\
\hline York & $159-257$ & Modern & Raymond and Bauer 2001b \\
\hline Hudson & -158 to 31 & 1384 & Raymond and Bauer 2001b \\
\hline
\end{tabular}

sedimentary organic matter in Lake Kasumigaura are different. Furthermore, the $\Delta^{14} \mathrm{C}_{\mathrm{DOC}}$ values in Lake Kasumigaura suggest apparently older ages than the age expected from the water residence time in the lake (200 days on average). Thus, it is likely that the highly ${ }^{14} \mathrm{C}$-depleted river DOC reduced the lake $\Delta^{14} \mathrm{C}_{\mathrm{DOC}}$ values, and that DOC in Lake Kasumigaura waters is composed of both old allochthonous DOC and young autochthonous DOC. Consequently, terrestrial sources are important contributors to DOC in Lake Kasumigaura.

\section{Elucidation of DOC Source from Paired Isotope Analysis}

The $\delta^{13} C_{\text {DOC }}$ values of the lake and river water samples ranged from $-25.9 \%$ o to $-24.2 \%$ o. These values are consistent with those of contemporary DOC (Schiff et al. 1990; Raymond and Bauer 
2001a). $\delta^{13} \mathrm{C}$ analyses of particulate and sedimentary organic matter in natural environments are generally used to distinguish between autochthonous and allochthonous origins (Meyers 1997; Watanabe et al. 2004), but the differences in the $\delta^{13} C_{D O C}$ values of the lake and river samples between spring (May) and autumn (September) were less than $1 \%$, except those of samples from Station 1 (Table 1). Because of this small difference, elucidation of DOC sources in Lake Kasumigaura by stable carbon isotope analyses alone is difficult.

On the other hand, the paired isotopic values of $\Delta^{14} C_{D O C}$ and $\delta^{13} C_{D O C}$ (Figure 2) show a markedly different pattern between spring and autumn values. The $\Delta^{14} C_{D O C}$ and $\delta^{13} C_{D O C}$ values of the lake samples during spring were heavier than those during autumn for all sampling sites. In contrast, $\Delta^{14} C_{D O C}$ values of the river samples did not show this trend, and their $\delta^{13} C_{D O C}$ values did not differ markedly between spring and autumn (Figure 2). As noted above, the ${ }^{14} \mathrm{C}$ dating results indicate that DOC of terrestrial origin accounted for a large proportion of the lake DOC. Thus, our paired isotopic measurements of DOC suggest a different proportion of allochthonous to autochthonous DOC in Lake Kasumigaura between spring and autumn.

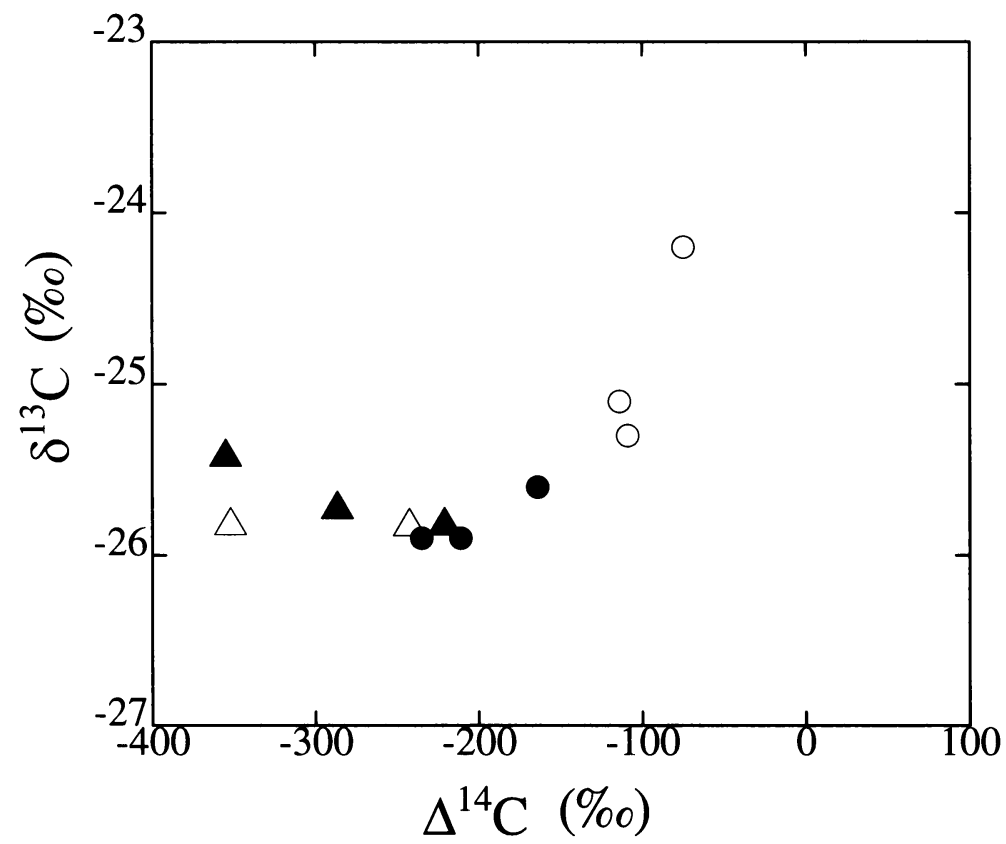

Figure $2 \Delta^{14} \mathrm{C}$ and $\delta^{13} \mathrm{C}$ values for DOC in Lake Kasumigaura and its flowing rivers in Lake Kasumigaura. Circles and triangles symbols indicate lake and river samples, respectively. Open and filled symbols indicate May and September samples, respectively.

This suggestion is supported by the relationships between the carbon isotope ratios and DOC concentrations (Figure 3a,b). Although the DOC concentration varied widely, from 3.3 to $1.7 \mathrm{mg} / \mathrm{L}$ in the riverine DOC samples, their $\Delta^{14} \mathrm{C}_{\mathrm{DOC}}$ and $\delta^{13} \mathrm{C}_{\mathrm{DOC}}$ values did not vary significantly. On the other hand, $\Delta^{14} \mathrm{C}_{\mathrm{DOC}}$ and $\delta^{13} \mathrm{C}_{\mathrm{DOC}}$ values of the lake DOC samples became heavier as the DOC concentration increased. Lake-water chlorophyll- $a$ concentrations, which are an indicator of primary productivity by phytoplankton, were much higher in spring than in autumn (Figure 3c,d). It is reported that as primary productivity in the lake increased in spring, ${ }^{13} \mathrm{C}$ might have become enriched as a result of decreasing C isotope fractionation (Yoshioka et al. 1994; Lehmann et al. 
2004). The increase of $\delta^{13} C_{D O C}$ values during spring periods accompanied with the increase of chlorophyll- $a$ concentrations could arise from $\mathrm{C}$ isotopic fractionation. Thus, the DOC composition in Lake Kasumigaura during spring might be strongly influenced by DOC of autochthonous origin. Moreover, both $\Delta^{14} C_{D O C}$ and $\delta^{13} C_{D O C}$ values of the lake samples obtained in autumn were similar to those of the river samples (Figure 2), indicating that riverine DOC contributed substantially to the lake DOC during autumn. Therefore, a seasonal change in the proportion of allochthonous to autochthonous DOC apparently occurred sometime between May and September.
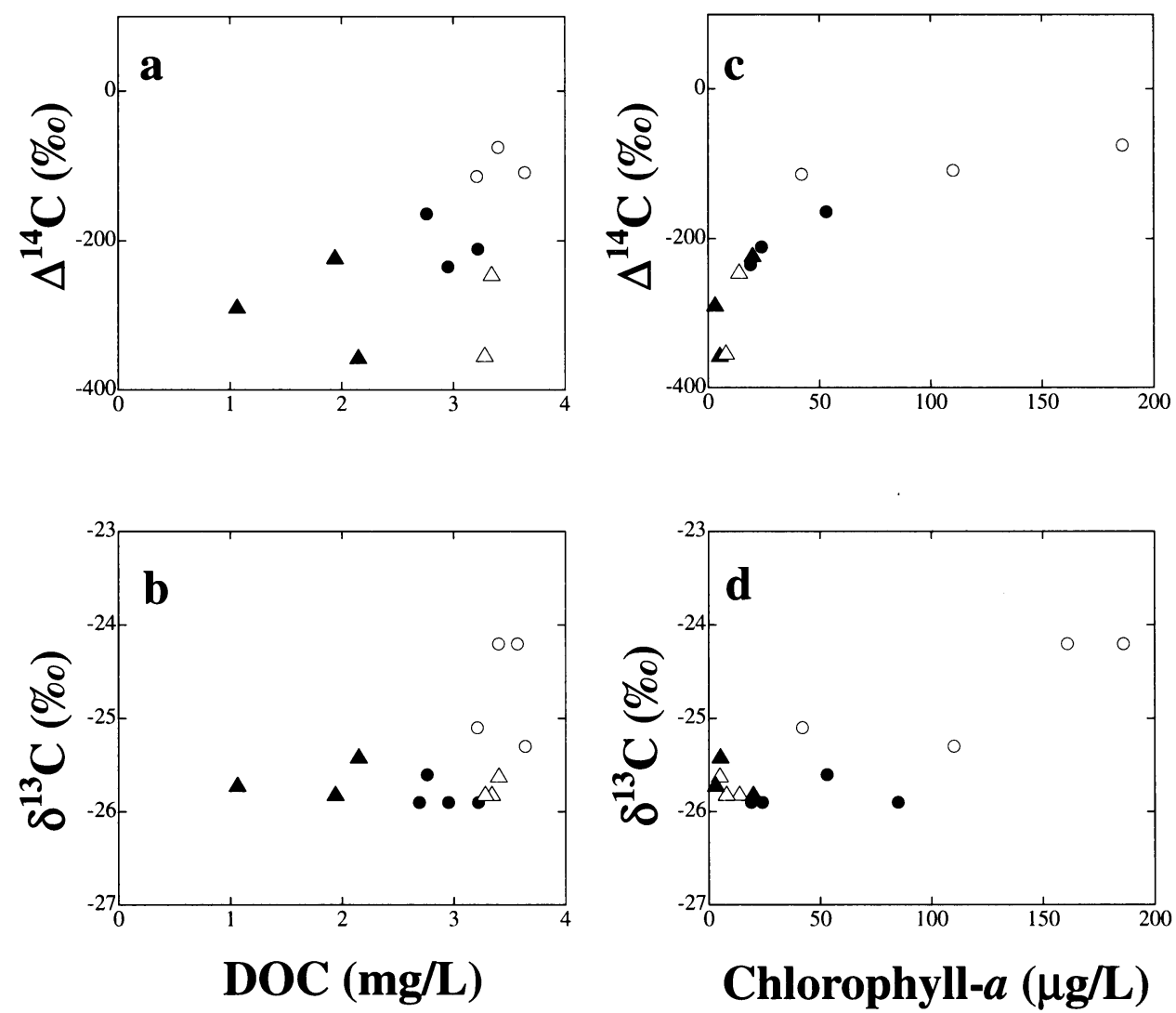

Figure 3 Relationships between isotopic measurements $\left(\Delta^{14} \mathrm{C}, \delta^{13} \mathrm{C}\right)$, chlorophyll- $a$, and DOC: a) $\Delta^{14} \mathrm{C}$ vs. DOC; b) $\delta^{13} \mathrm{C}$ vs. DOC; c) $\Delta^{14} \mathrm{C}$ vs. chlorophyll- $a$; d) $\delta^{13} \mathrm{C}$ vs. chlorophyll- $a$. Circles and triangles symbols indicate lake and river samples, respectively, and open and filled symbols indicate May and September samples, respectively. DOC were measured using a Shimadzu TOC-5000 total-organic-carbon analyzer. Chlorophyll- $a$ concentrations were estimated by a spectrophotometer after extraction with $100 \%$ methanol.

\section{CONCLUSION}

${ }^{14} \mathrm{C}$ dating of DOC in Lake Kasumigaura and its tributary rivers showed that the residence time of terrestrial organic matter is longer by thousands of years than that of the lake organic matter in sediments. Through the use of paired ${ }^{14} \mathrm{C}$ and ${ }^{13} \mathrm{C}$ measurements of DOC, we concluded that a seasonal change of DOC sources occurred in Lake Kasumigaura. Further isotopic analyses of DOC in lake environments should be conducted to determine the sources of lake DOC. 


\section{ACKNOWLEDGMENTS}

We thank Toshiyuki Kobayashi and Ryo Suzuki for the ${ }^{14} \mathrm{C}$ measurements at NIES-TERRA. This work was supported in part by a Grant-In-Aid for Scientific Research to Akio Imai (\#17310013) from the Ministry of Education, Science, Sports and Culture, Japan. The authors also acknowledge 2 anonymous reviewers for helpful comments and suggestions for improving this manuscript.

\section{REFERENCES}

Brown A, McKnight DM, Chin Y-P, Roberts EC, Uhle M. 2004. Chemical characterization of dissolved organic material in Pony Lake, a saline coastal pond in Antarctica. 2004. Marine Chemistry 89(1-4):327-37.

Cifuentes LA, Eldridge PM. 1998. A mass- and isotopebalance model of DOC mixing in estuaries. Limnology and Oceanography 43(8):1872-82.

Doval MD, Pérez FF, Berdalet E. 1999. Dissolved and particulate organic carbon and nitrogen in the northwestern Mediterranean. Deep-Sea Research I 46(3):511-27.

Hedges JI. 1992. Global biogeochemical cycles: progress and problems. Marine Chemistry 39(1-3):67-93.

Hopkinson Jr CS, Vallino JJ, Nolin A. 2002. Decomposition of dissolved organic matter from the continental margin. Deep-Sea Research II 49(20): 4461-78.

Kaiser K, Guggenberger G. 2000. The role of DOM sorption to mineral surfaces in the preservation of organic matter in soils. Organic Geochemistry 31(78):711-25.

Kaiser K, Guggenberger G, Zech W. 1996. Sorption of DOM and DOM fractions to forest soils. Geoderma 74(3-4):281-303.

Kelly CA, Coffin RB, Cifuentes LA. 1998. Stable isotope evidence for alternative bacterial carbon sources in the Gulf of Mexico. Limnology and Oceanography 43(8): 1962-9.

Lehmann MF, Bernasconi SM, McKenzie JA, Barbieri A, Simona M, Veronesi M. 2004. Seasonal variation of the $\delta^{13} \mathrm{C}$ and $\delta^{15} \mathrm{~N}$ of particulate and dissolved carbon and nitrogen in Lake Lugano: constraints on biogeochemical cycling in a eutrophic lake. Limnology and Oceanography 49(2):415-29.

Meyers PA. 1997. Organic geochemical proxies of paleoceanographic, paleolimnologic, and paleoclimatic processes. Organic Geochemistry 27(5-6): 213-50.

Meyers PA, Ishiwatari R. 1993. Lacustrine organic geochemistry - an overview of indicators of organic matter sources and diagenesis in lake sediments. Organic Geochemistry 20(7):867-900.

Raymond PA, Bauer JE. 2001a. DOC cycling in a temperate estuary: a mass balance approach using natural ${ }^{14} \mathrm{C}$ and ${ }^{13} \mathrm{C}$ isotopes. Limnology and Oceanography 46(3):655-67.

Raymond PA, Bauer JE. 2001b. Riverine export of aged terrestrial organic matter to the North Atlantic Ocean. Nature 409(6819):497-9.

Repeta DJ, Quan TM, Aluwihare LI, Accardi AM. 2002. Chemical characterization of high molecular weight dissolved organic matter in fresh and marine waters. Geochemica et Cosmochimica Acta 66(6):955-62.

Schiff SL, Aravena R, Trumbore SE, Dillon PJ. 1990. Dissolved organic carbon cycling in forested watersheds: a carbon isotope approach. Water Resources Research 26(12):2949-57.

Simjouw J-P, Minor EC, Mopper K. 2005. Isolation and characterization of estuarine dissolved organic matter: comparison of ultrafiltration and $\mathrm{C}_{18}$ solid-phase extraction techniques. Marine Chemistry 96(3-4): 219-35.

Stuiver M, Polach HA. 1977. Discussion: reporting ${ }^{14} \mathrm{C}$ data. Radiocarbon 19(3):355-63.

Watanabe T, Naraoka H, Nishimura M, Kawai T. 2004. Biological and environmental changes in Lake Baikal during the late Quaternary inferred from carbon, nitrogen and sulfur isotopes. Earth and Planetary Science Letters 222(1):285-99.

Williams PM, Druffel ERM. 1987. Radiocarbon in dissolved organic matter in the central North Pacific Ocean. Nature 330(6145):246-8.

Yamada Y, Ueda T, Wada E. 1996. Distribution of carbon and nitrogen isotope ratios in the Yodo River watershed. Japanese Journal of Limnology 57:46777. In Japanese.

Yoneda M, Shibata Y, Tanaka A, Uehiro T, Morita M, Uchida M, Kobayashi T, Kobayashi C, Suzuki R, Miyamoto K, Hancock B, Dibden C, Edmonds JS. 2004. AMS ${ }^{14} \mathrm{C}$ measurement and preparative techniques at NIES-TERRA. Nuclear Instruments and Methods in Physics Research B 223-224:116-23.

Yoshioka T, Wada E, Hayashi H. 1994. A stable isotope study on seasonal food web dynamics in a eutrophic lake. Ecology 75(3):835-46. 